中の位置が交互の周期をもって分子签的および力学的な 条件を異にすることか認められ，てれらの結果汃らての 系の分子の $20^{\circ} \mathrm{C}$ における平均の精造としての各炭素原 子は，分子の中心軸で垂直に交る分子容的および力学的 条件を異にする二つの平面を教光た場合に，順次ての平 面上あるいはその付近に 奇数炭素原子と倠数炭素原子 は，それぞれ一つの平面上に位㯰するような螺旋状の配 列をなしているべきであるという結論を得た。

そしてての飽和一掹基性脂肪酸分子に見られる奇数炭 素原子と偶数炭素原子とによる周期の関係は, 分子のも つ官能基の種類によって強弱に差があり，あるいは官能 基の欠除によってその周期が逆ともなるが，飽和 1 価ア ルコール，第 1 級アミン, パラフィン系炭化水素のいず れの采の分子についても認められ，ついでてれらの周期 から各系の分子の $20^{\circ} \mathrm{C}$ 亿おける取均の構造としての炭 素原子の配列形態を類推した結果，ての三つの系の分子 の炭素原子はいずれる螺旋状の配列をするが，館和 1 価 アルコールの分子では第 8 付近の宸素原子からはその奇 数と偶数とによる螺旋上の 周期性が次第に不規則とな ク，またパラフィン系炭化水素の分子では炭素数 8 付近 の分子にいたって初めて同様公安定度をもつ螺旋状配列 をすると共に，宸素原子の奇数と偶数とによる螺旋上の 周期的な交互の位置の関保が他の系の分子と全〈反対 と なり，第 1 积アミンの分子においては炭素数 3 付近の分 子からはぼ䭒和一盐基性脂肪酸の分子と同様な螺旋状の 炭素原子の配列となるであろうととが推定せられた。

\section{（第 $\mathbf{3}$ 報）}

\section{I. 緒}

\section{震}

著者らは第 1 報において，パランィン系炭化水素，館 和 1 価アルコール，第 1 級アミンおよび螕和一塩基性脂 肪酸の分子および沸点の関連について考察し，てれら四 つの采の液体分子はその炭素数か增すにしたがって，そ れぞれ炭菜鎖 $-\mathrm{CH}_{2-}-1$ 個の分子構造上の平均的な諸条 件は次第に接近し，分子の摩撚係数および安定度につい てはもちろん，分子の単位質量当りの笑容皘もまた次第 に接近しており，なおまた分子の炭素数が増すにしたが ってとの四つの系の炭素数の等しい分子の摩掽保数およ ひ安定度も次第に接近し，かつ分子の算位賀量当りの笑 容䅪もまた次第に接近しているべきてとを報告した。

そしてさらに著者は第2 報においててれら四つの系の 分子の $20^{\circ} \mathrm{C}$ における平均粠造としての炭素原子の配列 形態について報告したが，とてに第 2 報の炭素原子の配 列の示す平均的な分子の力学的状態と沸点との関係を求
めたところ, 分子の摩摖保数およびその安定度が等しく， かつ分子の単位賀量の占める笑容積が等しいときは液体 の沸点と，分子量，密度およびその密度をもづときの温 度の四者の間には明らかに一定の規律が存在するという 結果を得たので報告する。本報告に用いた諸種の測定㒹 はすべて International Critical Tablesによった。

\section{II. 钧和一塩基性脂肪酸, 畬和 1 価アルコ ール，第 1 极アミン，パラフィン系炭 化水素の 分子の $20^{\circ} \mathrm{C}$ における平均形 娒の鹿潔保数および安定度}

著者仙第 2 報において館和一㙁基性脂肪酸, 餙和 1 価 アルコール,第 1 級アミン,パラフィン系炭化水素の分子 の $20^{\circ} \mathrm{C}$ における平均の構造としての岸素原子の配列形 態を追求し，ての結梁とれら四つの系の分子は $20^{\circ} \mathrm{C}$ 亿お ける平均の形態としてその宸素原子はいずれも，分子の 中心軸で垂直に交る分子容的あるいは力学的条件を異に する二つの平面を考えた場合，ての平面上に順次奇数炭 蒵原子と偶数宸素原子とがそれぞれ一つの平面上あるい はその付近泣置するように螺旋発条状酒列し，そし

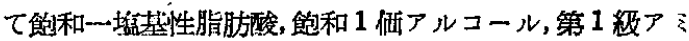
ンの分子では炭素数 5 の分子にいたって最初の螺旋環を 完了し，パラフィン系宸化水素の分子では宸素数 8 付近 の分子に至って紨めて他の三つの系の分子と同様な安定 度をもつ螺旋状配列をなすであううという䊅論を得た。

ゆえにいまての結論にしたがって分子の炭素原子がて のような螺犊状の配列を形成した場合，分子運動に際し てその分子の等擦你数および安定度はどのようになるか を考えるに，元来同一螺旋上の等しい貲点の力学的な条 件は全く等しかるべきであり，したがって分子の炭素原 子か等しい絓合半径をもってはほ正常な螺频を形成して いるかぎり，たとえ奇数炭素原子と偶数炭素原子との占 める位置が交互の周期性をもって分子容的および力学的 条件を異にしていでも各分子の摩摖係数およびその安定 度ははとんど等しかるべきである。さらになおての奇数 炭素原子と偶数炭素原子とによる周期の関係について は，分子運動に際して孷素原子が次第に安定な平衡を保 つため位置のエネルギーを小さくしようとし，飽和 1 価 アルコール分子に謬められるようにその条件が家次接近 するであろうこともまた容易に推湘せられる。

ゆえに館和一塩基性脂肪酸, 館和 1 伍アルコールおよ び第1 級アミンの分子ではすでに螺旋摆を形成している 炭素数 5 付近以上の分子から，またパラフィン系炭化水 素の分子では炭素数 8 付近以上の分子から， $20^{\circ} \mathrm{C}$ にお 
ける分子の平均の形態はいずれも単位資量当りの笑容栍 についてはもちろん，分子の摩擦係数および安定度もす べてはば等しくあるべきてとが考えられる。

以上は四つの系の分子の平均の形態についてである が，てのような分子の平均の形態は一眨に分子全体とし て示す性状，すなわち液体の一般的な物理化学的性状と 分子の形態との関係を求めるとき，個々の分子の形態と みなして取扱ってもなんら差支光はないわけである。

\section{III. 液体の漂点に関する法則}

以上のように館和一湓基性脂肪酸，飭和 1 俩アルコー ル，第 1 級ア ミンにおいては炭素数 5 付近以上の分子か ら，またパラフィン系炭化水素においては炭萦数 8 付近 以上の分子から，てれら四つの系のすべての分子の単位

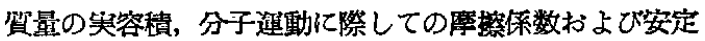
度がはとんど等しければ，てれらの分子をもつ液体の沸 点と他の物理的性状との間には，必然的になんらかの関 連がそれぞれはぼ等しい関係を保って成立していなくて 注ならぬととが推湘できる。そしてての沸点と関連を もっている物理的性状についてであるが，Walker らり が有機液体の沸点を分子量の函数として表わし，また Egloff 弓2) の外多数の 研究者も同様に沸点を 分子の㟶 素数の函数すなわち分子の質量の函数として表わして， それらの結果がきわめてよい成酷を得ている事然から， 液体の沸点は分子の資量ときわめて樑い関連をるってい るととが考光られる。しかしながら単に分子の筫量のみ が沸点を左右する要素であるともまだ考えられはいので
あうて，著者タらが報告した理想液体の比熱か晸度の函 数として装わされるととからも泷体の沸点法分子の質量 だけでなく，密既ともまた相当深い関俰を保っているこ とが考えられる。

ゆえに藷者は上記の単位筫量の才学的条件がはば等し い分子をもつ四つの系の液体につき，それぞれ沸点の提 氏温度 $T$ と, 分子量 $M, t^{\circ} \mathrm{C}$ における密度 $\rho$ との関 係を求めたととろ，てれらの間にははとんど一定の比例 定数 $k$ をもって次式の関保が成立しているととを知っ た。

$$
\begin{aligned}
M \rho^{2} & =k(T-t) \\
k & : \text { 比例定数（第 } 1 \text { 表ないし第 } 4 \text { 表参照） }
\end{aligned}
$$

そしてての式の成立を示す下の第 1 表ないし第 4 表の 結果は，液体分子の策位資量の笑容積が等しく，かつ分 子運動に際しての分子の摩摖俰数および安定度が等しい ときは，任意の一定温度加ら沸点までの温度差は分子量 とその温度における密度の 2 乗の積に比例するという普 漏的な一つの規律の 存在することを明らかに示してい る。

以下の各表は四つの系の液体について 任意の 温度を $20^{\circ} \mathrm{C}$ としたときの比例定数 $k$ の值を求めたものであり, なう表中点線より上の部分は $k$ の变化の状態を知るため 参考までそ揭げたものである。

\section{III. 結}

著者らはさきに第 1 報および第 2 報において飽和一塩 基性脂肪酸, パラフィン䒺炭化水素, 飽和 1 価アルコー

第 1 表 館和一塩基性脂肪酸

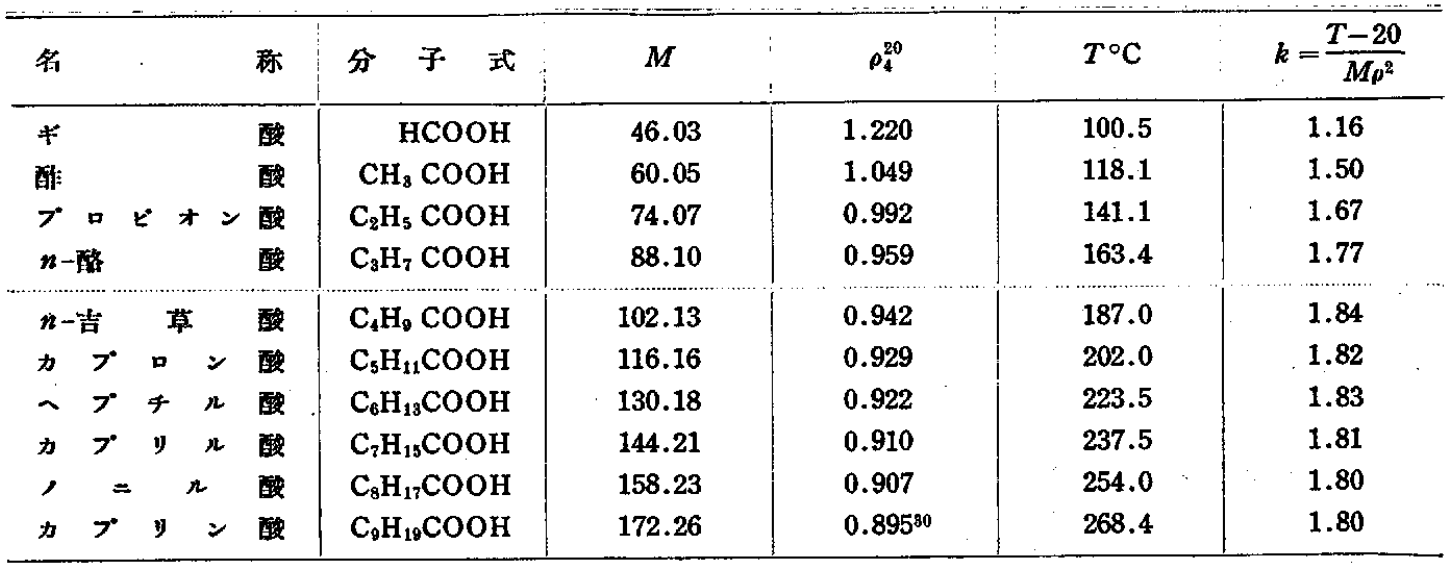

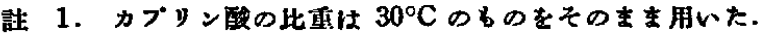

2. カプソン酸以上は常温に括いてすてに固体であるから，はぶいた。

1) J. Walker, J. Chem. Soc. 65, 193 (1894).

2) G. Egloff, J. Shermain, R. B: Dull, J. Phys. Chem.
44, $730(1940)$.

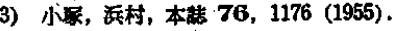


第 2 表 值和 1 価アルコール

\begin{tabular}{|c|c|c|c|c|c|}
\hline 名 & 分子式 & $M$ & $\rho_{4}^{20}$ & $T^{\circ} \mathrm{C}$ & $k=\frac{T-20}{M \rho^{2}}$ \\
\hline *チルアルコー & $\mathrm{CH}_{3} \mathrm{OH}$ & 32.03 & 0.792 & 64.5 & 2.20 \\
\hline$x+u>u=-u$ & $\mathrm{C}_{2} \mathrm{H}_{5} \mathrm{OH}$ & 46.05 & 0.789 & 78.5 & 2.04 \\
\hline nープロピルアルコール & $\mathrm{C}_{3} \mathrm{H}_{7} \mathrm{OH}$ & 60.06 & 0.804 & 97.8 & 1.98 \\
\hline 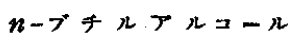 & $\mathrm{C}_{4} \mathrm{H}_{9} \mathrm{OH}$ & 74.08 & 0.810 & 117.7 & 2.01 \\
\hline$n-P \leqslant n>n=-n$ & $\mathrm{C}_{5} \mathrm{H}_{11} \mathrm{OH}$ & 88.09 & $0.817_{20}^{20}$ & 137.9 & 2.01 \\
\hline nーキキシルアルコール & $\mathrm{C}_{6} \mathrm{H}_{13} \mathrm{OH}$ & 102.11 & 0.820 & 155.8 & 1.98 \\
\hline ヘーへブチルアルコール & $\mathrm{C}_{7} \mathrm{H}_{15} \mathrm{OH}$ & 116.12 & $0.817^{22}$ & 175.8 & 2.01 \\
\hline ヘーオタチルアルコール & $\mathrm{C}_{8} \mathrm{H}_{17} \mathrm{OH}$ & 130.14 & 0.827 & 194.0 & 1.96 \\
\hline$n-1=ル\ulcorner ル コ-ル$ & $\mathrm{C}_{9} \mathrm{H}_{19} \mathrm{OH}$ & 144.15 & 0.828 & 215 & 1.97 \\
\hline 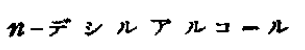 & $\mathrm{C}_{10} \mathrm{H}_{21} \mathrm{OH}$ & 158.17 & 0.829 & 231 & 1.94 \\
\hline$n$ ードデシルアルコール & $\mathrm{C}_{12} \mathrm{H}_{23} \mathrm{OH}$ & 186.20 & 0.831 & 295 & 1.85 \\
\hline
\end{tabular}

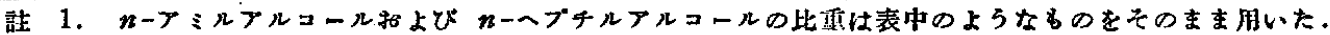
2. $n$ ードデシルアルコール付近以上は常温で周体であるので,はぶいた.

第 3 表 バラフィン系炭化水菜

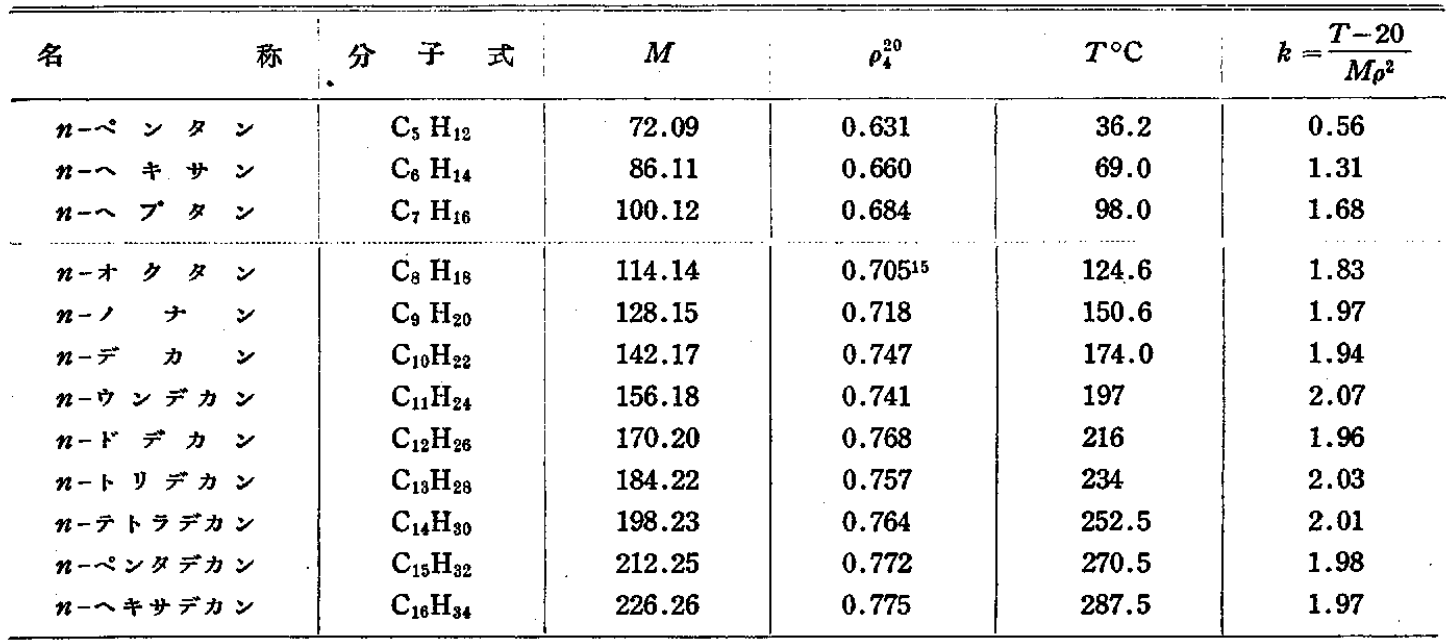

註 1. nーオクタンの比重は $15^{\circ} \mathrm{C}$ に乱いて湘定したるのであるが，そのまま用いた。

2. $n$ ヘペンタンまでは常温に括いて㑹体であり，nーヘキサデカン以上は固体であるのた，はぶいた.

第 4 表・第 1 級アミン

\begin{tabular}{|c|c|c|c|c|c|}
\hline 称 & 子 & $M$ & $\rho_{4}^{20}$ & $T^{\circ} \mathrm{C}$ & $k=\frac{T-20}{M \rho^{2}}$ \\
\hline nーブロピルアミン & $\mathrm{C}_{3} \mathrm{H}_{7} \mathrm{NH}_{2}$ & 59.08 & 0.719 & 48.7 & 0.94 \\
\hline$n-フ ゚ キ ル ア ミ ン ~$ & $\mathrm{C}_{4} \mathrm{H}_{9} \mathrm{NH}_{2}$ & 73.09 & 0.740 & 76.0 & 1.40 \\
\hline$n->\leqslant ル>ミ ン$ & $\mathrm{C}_{3} \mathrm{H}_{11} \mathrm{NH}_{2}$ & 87.11 & $0.766^{19}$ & 104.0 & .1 .64 \\
\hline nーへキシルアミン & $\mathrm{C}_{6} \mathrm{H}_{13} \mathrm{NH}_{2}$ & 101.12 & 0.771 & 128.0 & 1.80 \\
\hline 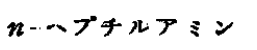 & $\mathrm{C}_{7} \mathrm{H}_{15} \mathrm{NH}_{2}$ & 115.14 & 0.777 & 155.1 & 1.94 \\
\hline nーオクキルアミン & $\mathrm{C}_{8} \mathrm{H}_{17} \mathrm{NH}_{2}$ & 129.15 & $0.777^{27}$ & 180.0 & 2.05 \\
\hline
\end{tabular}

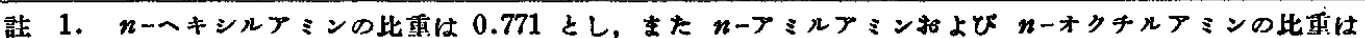
$19^{\circ} \mathrm{C}$ 扎ど $27^{\circ} \mathrm{C}$ で潮定したものであるがそのまま用いた.

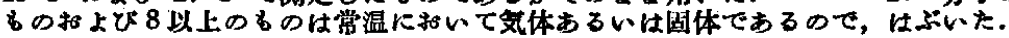


ルおよび第 1 級アミンの分子について沸点を左右する諸 要素を追求㭘討したが，ててに都者は分子運動に際して 単位筫量当りの力学的条件をはほ等しくしている液体を 選定し，てれによって液体の沸点と分子の質量および密 度との間の原則的な関係を求め，乙の結楽分子の単位資 堅の笑容積が等しく，かつ分子運動に際しての分子の摩 擦保数および安定庭が等しいときは，液体の沜点とてれ ら諸要素との間には次式のような一つの規倠のあるてと を知った。しかし式中 $M, T, \rho$ および $t$ はそれぞれ 分子量, 沸点の摄氏温度, 密度およびその密度をもつと きの液体の提氏温度である。

$$
M \rho^{2}=k(T-t)
$$

$k:$ 比例定数

そして分子の単位筫量の笑容積および力学的条件をほ ほ等しくしている浓体の比例定数 $k$ の值は，第 1 表ない し第4 表にはほ点線を㜔としてそれ以下に揭げたが，て れらの表中に見られる分子の力学的状熊の相違を示す $k$ の変化の推移は，との関係を得るために行った第 1 報お よび第 2 報の結論とほとんど合致する。

本一連の破労に際し終始御想篤なる御指導を睗わった 本学浜村保次教授に深く感謝の意を表子る。

（神戶大学理学部化学教综，神戶市東鹳区）（昭和 30 年 6 月 17 日受理）

\section{石灰石中に含まれる微量マグネシゥムの存在状慜（その 1３）}

北野康

\section{（その 1） 存在状態の新決定法}

\section{緒}

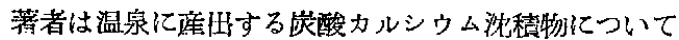
化学的研究を行い，得られた結果についてはその都度報 告りしてきた。淡積物に含まれる徽量元素の存在状態は 生成系の状態によって定まると考光られ，また風化によ る元素の移動にも重大な影響を与えるととは明らかであ る。すなわち沈積物の微量成分の含有量と微量成分の存 在形とは大きな関連がある。天然に座㫫する炭陵カルシ ウムが生成された環境，条件等を厳密に知ることは地球 化学的にみて重要な慧昧がある。現在までに著者は主成

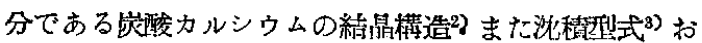
よび化学成分》等を知ることによって生成持の環境を明 らかにする知識か得られるととを報告してきたが，微量

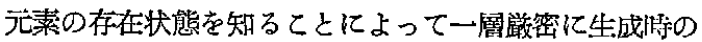
環境を知るととができると予想される。そこでツ上述べ たような目的で著者は天然産石灰石中の微量マグネシウ ムの存在状熊を浃定しようと武みて成功したので，とし にその新浃定法について報告する。徉来はごく微量のマ グネシゥムの存在状態の決定は不可能であった。

1) 北野, 本就 74, 380 (1953); 74, 789 (1953); 75, 125 (1954); 75,129 (1954); 76, 582 (1955).

2) 北野, 本諾 76, 582 (1955).

3) 北野, 本誌 74, 380 (1953); 74, 789 (1953).

4) 北野, 本梽 75, 125 (1954).

\section{方 針}

一般に天然産石灰石の分析絬果 ${ }^{5}$ から石灰石中のマグ ネシウムは炭酸塩として入っていると考光られる。こう 考えるとマグネシウムは宸酸マグネシウム*1かドロマイ 卜 $\mathrm{CaMg}\left(\mathrm{CO}_{3}\right)_{2}$ として存在すると一般には考光られ る*。なぜるらば炭酸カルシウム中のカルシウムの任意 の場所にマグネシウムが入りとむととは結晶学上からは 一般には考え難くある定った場所に入りやすいからであ

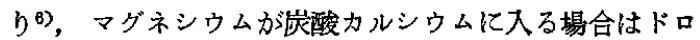
マイトか炭酸マグネシウムかのいずれかの形で入ってい る場合が大部分だと考えてよい。したがってどく微量の マグネシウムの存在状態を涣定するためにはマグネシウ ムがドロマイトとして入っているか，炭酸マグネシウム として入っているかをまずとこでは決定するという比輘

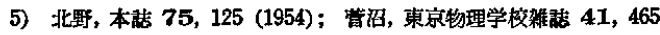
(1932); F. W. Clarke, "The Data of Geochemistry" p. 564 (1924) Washington 等参想. マグネシゥムは大体酸化マ グネシウムとして 0.01 1\% 位含有されている.

"1 炭酸マグネシウムと塩基性炭酸マグネシウムの雨者を含めて，て てでは炭酸マグネシウムという，以下てれにしたがう。

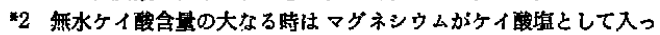
ているかる知れないが，こてでてういう場合を除外して教える。

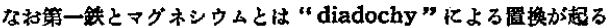
てとも考元られるので，一概にドロマイトか岸酸マグネシウムか と結論つけられない。が一般的机てう云えるであろう。

6) とのととに関しては昔から多数の論交がある。たと光ば最近では

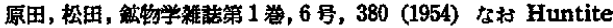

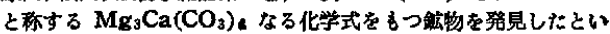
う報交があるが; とれは特例とみてよいであろう. G.T. Faust, Am. Mineralogist. 38, 4 (1953). 